\title{
INTERNATIONAL JOURNAL OF

\section{A STUDY ON THE ACCEPTANCE OF DIFFERENT FORMS OF ELECTRONIC BANKING IN INDIA: CHALLENGES AND OPPORTUNITIES}

Ms. Kruti Shah*1, Dr. K.D.Naik ${ }^{2}$

${ }^{* 1}$ Lecturer, Department of Commerce and Business Management, The Maharaja Sayajirao University Of Baroda, INDIA

${ }^{2}$ Assistant Professor, Department of Commerce and Business Management, The Maharaja Sayajirao University Of Baroda, INDIA

\section{Abstract:}

Over the past couple of years, the Indian Banking System has shown great resilience with the developing economy of the nation. The banking industry has not only grown in number but has also shown a tremendous development in the technological front. The banking industry has given lot of options to the customers to use banking services with the help of technology. This research paper focuses on the types of electronic banking media; the past, the present and the hopeful future of the banking system. This paper focuses on the levels of acceptance of electronic banking media among the customers and also focuses on the reasons of differing levels of acceptance. This research paper also tries to define the challenges faced by the banking system in the growth of acceptance level by the customers towards electronic banking and the opportunities which can be banked on in the form of marketing strategies that help the acceptance of electronic banking media for the faster and better services. The challenges and opportunities in the electronic banking sector are judged upon the various sources of information available and an attempt is made to show the probable future trend in the acceptance of electronic banking media by the society at large.

Keywords:

Electronic Banking, banking industry, banking services, marketing strategies, customers.

Cite This Article: Ms. Kruti Shah, Dr. K.D.Naik, "A STUDY ON THE ACCEPTANCE OF DIFFERENT FORMS OF ELECTRONIC BANKING IN INDIA: CHALLENGES AND OPPORTUNITIES" International Journal of Research - Granthaalayah, Vol. 3, No. 7(2015): 12-22. DOI: https://doi.org/10.29121/granthaalayah.v3.i7.2015.2979.

\section{INTRODUCTION}

The advent of Information technology has made a great impact on the banking sector. A rapid transformation has been seen in the services offered by the Indian Banking system. May it be the initial computerization into branch banking, the ATM services, online transactions, much promoted Mobile banking or the plastic cards easy money; these all have helped the services to move faster and serve better. The credit of launching internet banking in India goes to ICICI Bank. Citibank and HDFC Bank followed with internet banking services in 1999. Several initiatives have been taken by the Government of India as well as the Reserve Bank to facilitate 


\section{INTERNATIONAL JOURNAL OF RESEARCH -GRANTHAALAYAH \\ A knowledge Repository}

Management

the development of e-banking in India. The Government of India enacted the IT Act, 2000 with effect from October 17, 2000 which provided legal recognition to electronic transactions and other means of electronic commerce. In spite of the great benefits of the electronic banking, it is extremely essential that banks regard the risks associated with it. One significant step that banks must take before going through any transformation is to insure the proper handling of electronic banking risk (Al-Alawi, 2005). E-based banking is also known as Cyber banking, home banking, and virtual banking and includes various banking activities that can be conducted from anywhere (Dheenadhyayalan 2010).

\section{E-Banking:}

E-banking is a generic term making use of electronic channels through telephone, mobile phones, internet etc. for delivery of banking services and products.

Online banking services provided by banks are as follows -

- Core Banking Solution(CBS)

- Automated Teller Machine (ATM)

- Electronic Fund Transfer (EFT)

- Real Time Gross Settlement System (RTGS)

- National Electronic Fund Transfer(NEFT)

- Mobile Banking (M-Banking)

- Electronic Clearing Services (ECS)

- Plastic Cards (Credit and Debit Card)

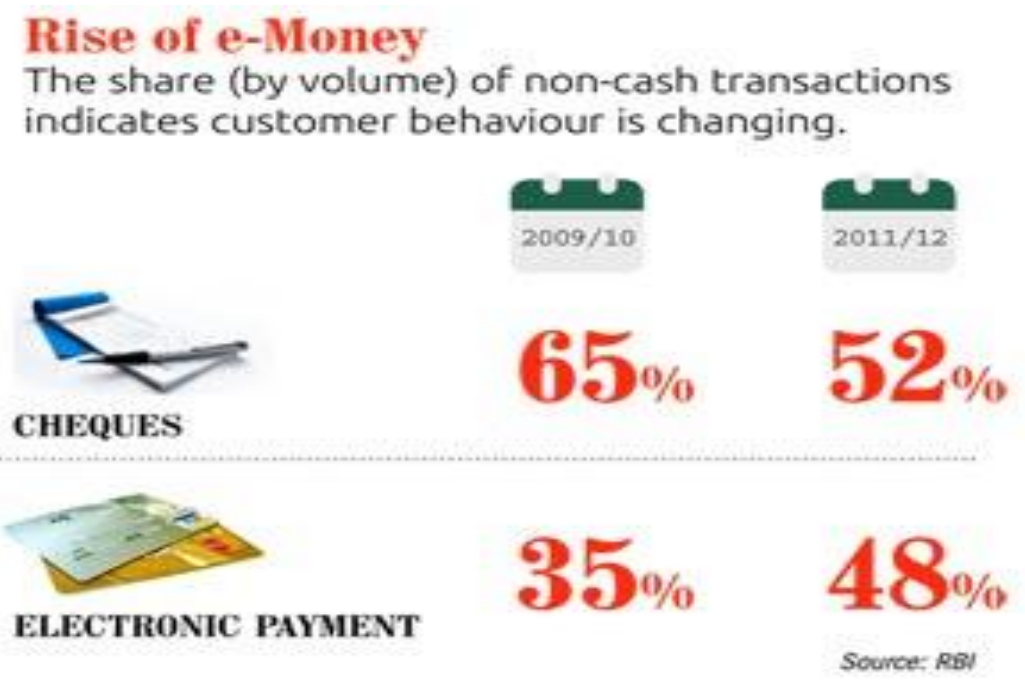

As per the above figure shows that there has been a rise in the e-money i.e. the customer behaviour is changing as the percentage of cheques used in FY2009-10 were 65\% and it came down to 52\% in FY2011-12.Simultaneously, the payment through e- banking increased to 48\% in the FY2011-12 from 35\% in the FY209-10. 


\section{INTERNATIONAL JOURNAL OF RESEARCH -GRANTHAALAYAH \\ A knowledge Repository}

Management

\section{Consumer acceptance of Internet banking:}

Raghavan (2006) opined that at present, over $85 \%$ of the finished payment transactions are electronic and traditional way of doing banking at the branch level has relatively little importance to electronic banking users. Many banks, including PSU banks, would have online ATMs, phone banking, virtual banking, e-banking, Internet banking, etc. by 2020. Mohan (2006) remarked that Indian banking is at the threshold of a paradigm shift and a significant development has been achieved by banks in offering a variety of new and innovative e-banking services to customers today, which was not thought of before. Shukla and Shukla (2011) stated that E-banking offers a higher level of convenience for managing one's finances even from one's bedroom. However, it continues to present challenges to the financial security and personal privacy. Customers are advised not to share personal information like PIN numbers, passwords etc with anyone, including employees of the bank; change ATM PIN and online login and transaction passwords on a regular basis; ensure that the logged in session is properly signed out. A review of this information shows that there is a greater amount of acceptance for electronic banking among customers yet there are a few challenges that are hindering its growth.

\section{METHODOLOGY}

The research is based on secondary source of information available and is mainly based on exploratory research design.

An attempt is made to understand the different challenges and the opportunities available for the acceptance of different forms of electronic banking. The sources of data are Report on Trends and Progress of Banking in India published by Reserve Bank of India, Mumbai. The parameters of the study have been restricted to the growth of e-commerce, cards transactions-debit card and credit card, mobile banking and growth of ATMs.

An attempt has been made to compare the past data with the present available statistics and to check on the opportunities available to increase the share of electronic banking as a media of transacting.

\section{RESEARCH OBJECTIVES}

Primary Objective: To understand the acceptance of different forms of E-Banking in India.

Other Objective: To understand the challenges and the opportunities available in the electronic delivery channels for better banking services. 


\section{INTERNATIONAL JOURNAL OF RESEARCH -GRANTHAALAYAH \\ A knowledge Repository}

Management

\section{FINDINGS \& DISCUSSIONS}

\subsection{GROWTH OF E-COMMERCE}

E-commerce activities started in India since late '90, but the e-commerce services picked up growth only after FY 2007. The figure(1) below shows the growth of e-commerce from approximately US $\$ 1800$ million in year 2007 and just in a span of 4 years it reached the mark of US\$ 1 billion in the year 2011. Ever since that, with the advent of new technology, the ecommerce activities have shown a positive trend and tremendous growth in the acceptance of internet or online activities.

With the increase of e-commerce activities, the banking sector has also grown its activities and has benefitted a lot in terms of volume of transactions and also value of transactions. With the initiation of online banking the customers have experienced ease in transacting with the betterment of services.

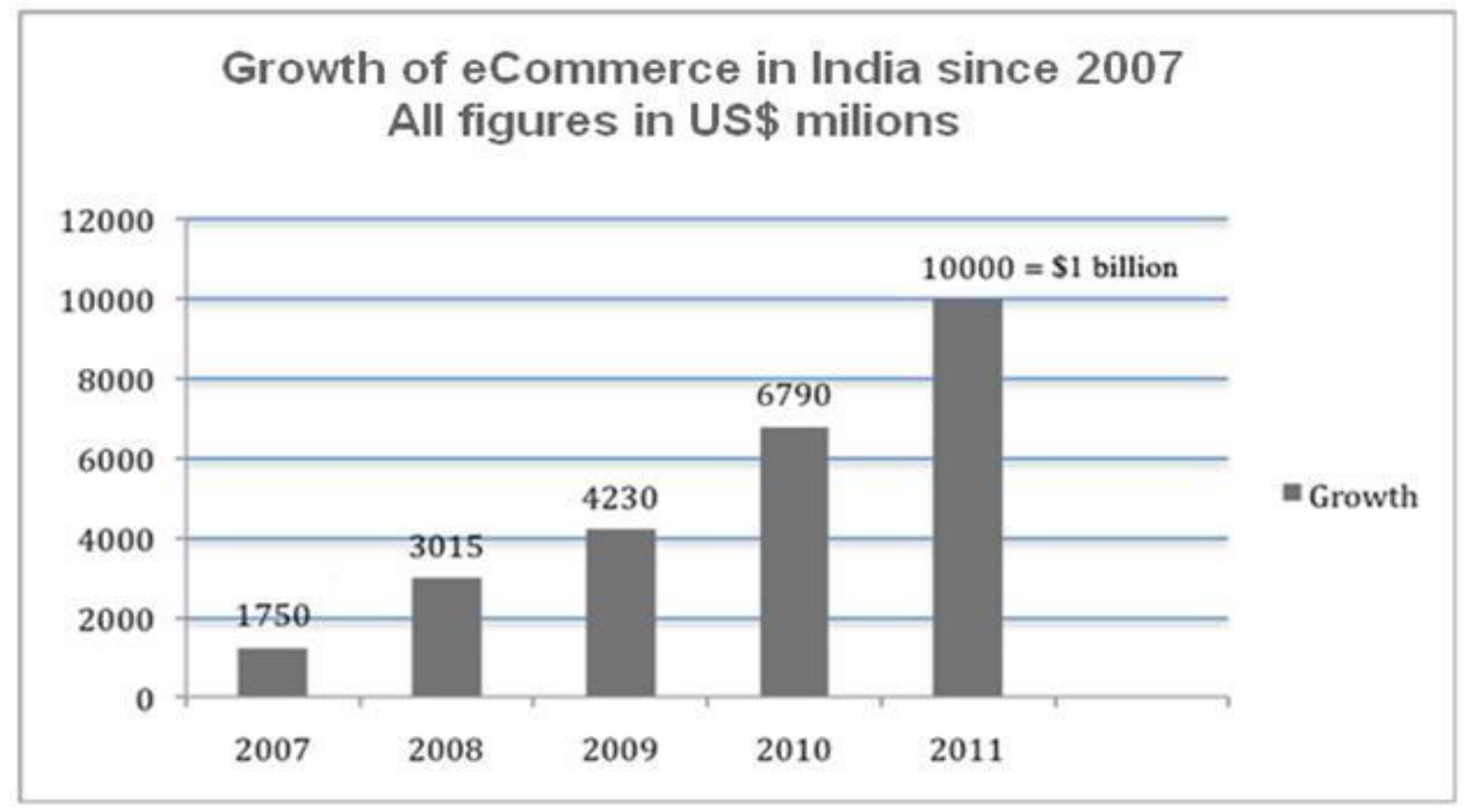

\subsection{CARDS TRANSACTION}

Debit card: Debit card is a card that is offered to customer to withdraw own money from the bank any time. It is also called a plastic card. Debit card is used for cash withdraw from ATM, funds transfer, paying bills, accessing detail account information, etc. 


\section{INTERNATIONAL JOURNAL OF RESEARCH -GRANTHAALAYAH \\ A knowledge Repository}

Management

Credit card: Credit card is like a credit offered by bank to the customer. The Credit Card holder is empowered to spend money wherever and whenever he wants with his Credit Card within the limits fixed by his bank.

The table below shows the card based payment transaction in value (Rupees Crores).

The data is shown for the FY 2005-06 to FY 2009-10. This data shows a positive trend in usage of both the cards i.e. debit and credit cards.

The data of Credit card transactions have shown an increase of 54\% approximately, from the FY 2005-06 to FY 2009-10.

The data of Debit Card transactions shows an increase of $22 \%$ approximately, from the FY 200506 to FY 2009-10.

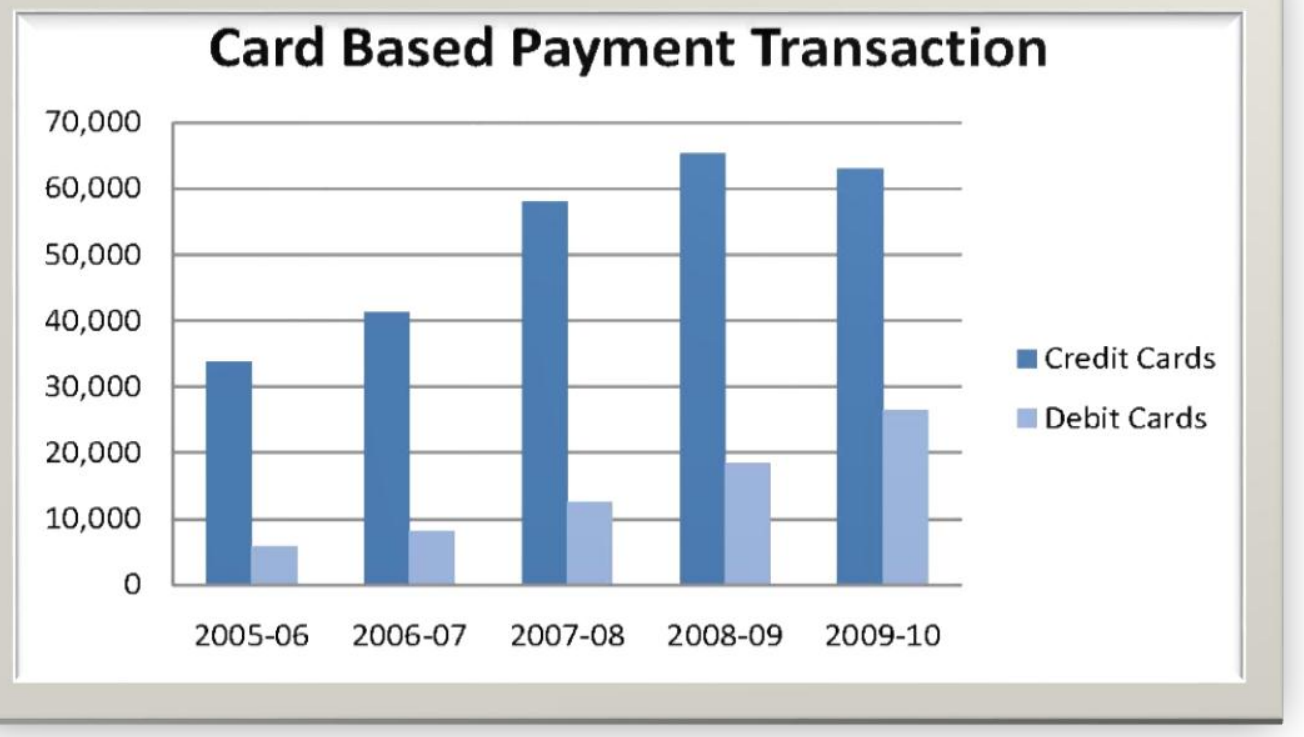

Source: RBI, Annual Report 2009-10

Table 1: Showing Card based payment Transaction Value (Rupees Crores)

\begin{tabular}{|l|l|l|l|l|l|}
\hline Category & $2005-06$ & $2006-07$ & $2007-08$ & $2008-09$ & $2009-10$ \\
\hline Credit Cards & 33,886 & 41,361 & 57,985 & 65,356 & 62,950 \\
\hline Debit Cards & 5,897 & 8,172 & 12,521 & 18,547 & 26,566 \\
\hline
\end{tabular}




\section{INTERNATIONAL JOURNAL OF RESEARCH -GRANTHAALAYAH

\section{PAYMENTS CARR}

Card Type

Debit Cards

Credit Cards

\section{Volume (Mar 2014)* \\ Annual Growth}

Source: RBI-Banking Sector Performance Analytics Data for Public Access

P.N: The latest data on cards payment in value is not available.

The chart above shows the latest information about payments via plastic cards in transaction volume. The debit card transactions volume in March 2014 shows 394.42 million of transaction and thus an annual growth of $17.2 \%$. The growth of volume of transactions of debit card is more than credit cards because the customers use debit cards more for balance inquiry and is also accepted widely by the Rural India.

\section{Challenges}

- There is still lack of trust towards acceptance of plastic cards as mode of transacting.

- There is also distrust towards misuse of debit card especially during online transactions as the amount directly gets debited form the account and immediately.

- At POS Terminals, the cards sometimes do not get scratched due to poor connectivity

\section{Opportunities}

- The RBI can issue a knowledge source in the different local languages to educate the people about the usage and benefits of plastic cards to rural India.

- The initiation of personalized debit cards and pictures of personal liking to be printed on plastic cards seems to be a good proposal to increase the sale and use both of the plastic cards.

- If choice in choosing the PIN or registering the PIN Number of personal choice with the bank; the bank can attract more customers.

- Special educational programs can be giving in public interest especially to the potential customers of rural India can help the growth in usage of plastic cards. 


\section{INTERNATIONAL JOURNAL OF RESEARCH -GRANTHAALAYAH \\ A knowledge Repository}

Management

\subsection{MOBILE BANKING}

Mobile banking services are offered to the customers by registering their mobile numbers with the bank at the time of opening the account.

Mobile banking is used for performing balance inquiry, account transactions, payments etc. via a mobile phone. Mobile banking is performed via SMS or the Mobile Internet, but can also use special programs downloaded to the mobile device in the form of bank applications.

The chart below shows the mobile banking transactions in volume and value (in million) for the FY 2010-11 to FY 2012-13. The trend is positive as there is continuous growth in both volume and values of transactions.

\begin{tabular}{|c|c|c|c|}
\hline Year & $\begin{array}{c}\text { No. of Users } \\
\text { (Million) }\end{array}$ & $\begin{array}{c}\text { Volume } \\
\text { (Million) }\end{array}$ & $\begin{array}{c}\text { Value } \\
\text { (Billion Rs.) }\end{array}$ \\
\hline $2010-11$ & 5.96 & 6.85 & 6.14 \\
\hline \multirow{2}{*}{$2011-12$} & 12.96 & 25.56 & 18.21 \\
\cline { 2 - 4 } & $(117.45 \%)$ & $(273.139 \%)$ & $(196.58 \%)$ \\
\hline \multirow{2}{*}{$2012-13$} & 22.51 & 53.30 & 59.90 \\
\cline { 2 - 4 } & $(73.69 \%)$ & $(108.53 \%)$ & $(228.94 \%)$ \\
\hline
\end{tabular}

The graph below is the representation of the chart which represents the growth of mobile banking transactions from the FY 2011, August to FY2013, August.






\section{INTERNATIONAL JOURNAL OF RESEARCH -GRANTHAALAYAH \\ A knowledge Repository}

\section{Challenges}

- The poor internet connectivity can prove to be a hindrance in transacting with the help of mobile.

- The mobile applications of banks support only a few handsets and do not work correctly if the mobile phone.

- There can be a delay in the confirmation message even after the transaction through mobile banking.

- Unlike ATM, the mobile banking services are not available in other language than English.

\section{Opportunities}

- The mobile applications should be developed in such a way that supports most of the handsets.

- The mobile applications should be available in Hindi language too like ATM.

\subsection{AUTOMATED TELLER MACHINE (ATM)}

ATM is an electronic machine which allows the customer to withdraw cash, check account balances, transfer fund, and get account statement and other banking services.

On most modern ATMs, the customer is identified by inserting a plastic ATM card with a magnetic stripe or a plastic smart card with a chip that contains a unique card number and some security information such as an expiration date or CVVC(CVV). Authentication is provided by the customer entering a personal identification number (PIN).

The below Annexure 1 gives an exhaustive list of the banks and the number of ATMs of each bank and their status till the quarter end of September, 2014.

\begin{tabular}{|l|c|c|c|c|c|}
\hline \multicolumn{7}{|c|}{ ANNEXURE I } \\
\hline \multicolumn{7}{|c|}{ Region wise deployment of ATMs for the quarter ended September, 2014 } \\
\hline \multicolumn{7}{|c|}{ Bank Name } & $\begin{array}{c}\text { Metro } \\
\text { Centers }\end{array}$ & $\begin{array}{c}\text { Urban } \\
\text { Centers }\end{array}$ & $\begin{array}{c}\text { Semi - } \\
\text { Urban } \\
\text { Centers }\end{array}$ & $\begin{array}{c}\text { Rural } \\
\text { Centers }\end{array}$ & $\begin{array}{c}\text { Total of all } \\
\text { centers }\end{array}$ \\
\hline Scheduled Commercial Banks \\
\hline Public Sector Banks \\
\hline Nationalized Banks & 273 & 371 & 252 & 225 & 1121 \\
\hline Allahabad Bank
\end{tabular}




\section{INTERNATIONAL JOURNAL OF RESEARCH -GRANTHAALAYAH

\begin{tabular}{|c|c|c|c|c|c|}
\hline Andhra Bank & 439 & 603 & 587 & 391 & 2020 \\
\hline Bank of Baroda & 1947 & 1671 & 1566 & 1841 & 7025 \\
\hline Bank of India & 845 & 1655 & 1708 & 1539 & 5747 \\
\hline Bank of Maharashtra & 453 & 372 & 418 & 596 & 1839 \\
\hline Canara Bank & 2071 & 1755 & 1594 & 1675 & 7095 \\
\hline Central Bank of India & 1031 & 1029 & 1069 & 966 & 4095 \\
\hline Corporation Bank & 695 & 717 & 827 & 507 & 2746 \\
\hline Dena Bank & 328 & 285 & 326 & 493 & 1432 \\
\hline Indian Bank & 430 & 599 & 591 & 566 & 2186 \\
\hline Indian Overseas Bank & 760 & 821 & 899 & 802 & 3282 \\
\hline Oriental Bank of Commerce & 548 & 680 & 656 & 565 & 2449 \\
\hline Punjab and Sind Bank & 140 & 346 & 208 & 469 & 1163 \\
\hline Punjab National Bank & 1907 & 2022 & 1732 & 2293 & 7954 \\
\hline Syndicate Bank & 598 & 705 & 748 & 865 & 2916 \\
\hline UCO Bank & 493 & 529 & 537 & 592 & 2151 \\
\hline Union Bank of India & 1907 & 1866 & 1629 & 1226 & 6628 \\
\hline United Bank of India & 255 & 515 & 444 & 545 & 1759 \\
\hline Vijaya Bank & 367 & 421 & 397 & 369 & 1554 \\
\hline \multicolumn{6}{|l|}{ State Bank Group } \\
\hline State Bank of India & 9948 & 16040 & 14428 & 4975 & 45391 \\
\hline State Bank of Bikaner \& Jaipur & 319 & 469 & 615 & 278 & 1681 \\
\hline State Bank of Hyderabad & 465 & 713 & 780 & 427 & 2385 \\
\hline State Bank of Mysore & 296 & 308 & 306 & 299 & 1209 \\
\hline State Bank of Patiala & 193 & 367 & 362 & 397 & 1319 \\
\hline State Bank of Travancore & 105 & 351 & 885 & 99 & 1440 \\
\hline \multicolumn{6}{|l|}{ Other Public Sector Banks } \\
\hline IDBI Bank & 757 & 1095 & 597 & 278 & 2727 \\
\hline Total & 27570 & 36305 & 34161 & 23278 & 121314 \\
\hline \multicolumn{6}{|l|}{ Private Sector Banks } \\
\hline Catholic Syrian Bank Ltd. & 42 & 91 & 94 & 6 & 233 \\
\hline City Union Bank Ltd & 204 & 369 & 336 & 86 & 995 \\
\hline Dhanalaxmi Bank Ltd. & 141 & 127 & 110 & 18 & 396 \\
\hline Federal Bank Limited & 224 & 302 & 809 & 100 & 1435 \\
\hline ING Vysya Bank & 384 & 189 & 49 & 13 & 635 \\
\hline Jammu \& Kashmir Bank & 45 & 362 & 250 & 194 & 851 \\
\hline Karnataka Bank Ltd. & 244 & 248 & 197 & 69 & 758 \\
\hline Karur Vysya Bank Ltd & 313 & 490 & 613 & 221 & 1637 \\
\hline Lakshmi Vilas Bank Ltd. & 130 & 80 & 228 & 200 & 638 \\
\hline
\end{tabular}




\section{INTERNATIONAL JOURNAL OF RESEARCH -GRANTHAALAYAH

\begin{tabular}{|c|c|c|c|c|c|}
\hline Ratnakar Bank Ltd. & $\mid 141$ & 96 & $\mid 112$ & 29 & 378 \\
\hline South Indian Bank Ltd & 185 & 277 & 481 & 120 & 1063 \\
\hline Tamilnadu Mercantile Bank Ltd. & 76 & 181 & 331 & 161 & 749 \\
\hline Axis (UTI) Bank Ltd. & 4306 & 3995 & 3304 & 1541 & 13146 \\
\hline Development Credit Bank Ltd. & 140 & 37 & 53 & 22 & 252 \\
\hline HDFC Bank Ltd. & 4838 & 3318 & 2497 & 862 & 11515 \\
\hline ICICI Bank Ltd. & 6027 & 3496 & 1761 & 455 & 11739 \\
\hline IndusInd Bank Ltd & 698 & 357 & 144 & 78 & 1277 \\
\hline Kotak Mahindra Bank Ltd & 814 & 184 & 111 & 50 & 1159 \\
\hline Yes Bank Ltd. & 656 & 362 & 114 & 17 & 1149 \\
\hline Total & 19608 & 14561 & 11594 & 4242 & 50005 \\
\hline \multicolumn{6}{|l|}{ Foreign Banks } \\
\hline RBS (ABN AMRO) & 52 & 8 & 0 & 0 & 60 \\
\hline CITI Bank & 416 & 110 & 20 & 31 & 577 \\
\hline DBS Ltd. & 30 & 1 & 0 & 0 & 31 \\
\hline Deutsche Bank & 26 & 13 & 0 & 0 & 39 \\
\hline FirstRand Bank & 12 & 0 & 0 & 0 & 12 \\
\hline HSBC & 133 & 10 & 0 & 0 & 143 \\
\hline Standard Chartered & 223 & 56.00 & 0 & 0 & 279 \\
\hline Total & 892 & 198 & 20 & 31 & 1141 \\
\hline Grand Total & 48070 & 51064 & 45775 & 27551 & 172460 \\
\hline
\end{tabular}

\section{Challenges}

- Although the ATMs have grown in number, many a times it is observed that the machines are out of service for sometime.

- Not all the off-site ATMs are protected byt the gaurds all the time.

- There is no alternative to transact on ATM if the PIN(personal identification number) is lost.

- The generation of new PIN(personal identification number) also takes time.

\section{Opportunities}

- The customers In rural India can be educated through training sessions on benefits of electronic banking, in public interest .

- If off-ite ATMs are gaurded properly, the transactions can take place smothly $24 \mathrm{hrs} * 7$ days.

- Like a few banks, if all the banks go for Cah Deposit and Cheque deposit machines, the use of electronic banking can be encouraged and the branch banking work can be eased. 


\section{INTERNATIONAL JOURNAL OF RESEARCH -GRANTHAALAYAH \\ A knowledge Repository}

Management

\section{LIMITATIONS OF THE STUDY}

- The study is restricted to only three forms of electronic banking viz. Debit Cards and Credit Cards, Mobile Banking and ATM so as to narrow the area of research.

- The data is analyzed on the basis of availability of information.

- The data collected is not taken for every year or no constant slabs of years are maintained because the data are taken on the basis of availability and just to portray the trend of considerable past period and the considerable present.

- The futuristic trend in the form of opportunities is just an attempt to predict the future growth of electronic banking forms and its wide acceptance with the help of such suggestions.

- The present data which is shown in comparison to past data, are on the availability of the latest data available for that particular form of e banking.

\section{CONCLUSION}

It is known from the above data that Electronic media has helped and given tremendous growth to the banking sector. Also the issues of security of personal data that customers faced are solved by the RBI regulations to a greater extent. Yet there is no doubt that still the air of distrust among the customers is there while transacting online. This is mainly due to the past experiences and lack of security and also due to the increment of cyber frauds by the day. As per the continuous positive trend in the growth of electronic banking, it can be said that banking sector is on a boom and has a great acceptance among customers. The banking industry can grow further if the customers in the rural market are more educated and if they consider electronic banking media as more user friendly than just branch banking.

\section{REFERENCES}

[1] Ahmad,Uddin Jayanal and Raul, R.K (2005), public sector banks in India impacts of financial sector reforms, new Delhi, kalpaz publication,pp-81

[2] Shimizu, Satoshi (2010), The State of the Indian Banking Sector and its Role in India's High Growth, Pacific Business and Industries Vol. X, 2010 No. 36

[3] Statistical tables relating to banks in India 2010-11, reserve bank of India

[4] Statistical tables relating to banks in India 2009-10,reserve bank of India

[5] Rayudu,C.S,(2004),E-commerce E-business,Nagpur, Geetangali Press Pvt LTD,PP-74

[6] Sawant, B.S. (2011), Technological Developments in Indian Banking Sector, Vol.1,Issue.IX/Sept;11pp.1-4

[7] Nafees A. Khan and Ms. Fozia, International Journal for Advanced Research in Management and Social Sciences, ISSN 2278- 62. 